\title{
Biogenic Zinc Oxide Nanoparticles Synthesis Using Tabernaemontana Divaricate Leaf Extract and Its Anticancer Activity against MCF-7 Breast Cancer Cell Lines
}

\author{
Rajeshwari Sivaraj*, Pattanathu KSM Rahman, P. Rajiv, and Rajendran Venckatesh
}

\begin{abstract}
This investigation explains the biosynthesis and characterization of zinc oxide nanoparticles from an Indian medicinal plant by an eco-friendly method. The main objective of this study is to synthesize zinc oxide nanoparticles from Tabernaemontana divaricate leaves through a green chemistry approach. Highly stable, spherical zinc oxide nanoparticles were synthesized by using 50\% concentration of Tabernaemontana leaf extract. Formation of zinc oxide nanoparticles have been characterized by X-ray diffraction (XRD), Raman spectroscopy and transmission electron microscopy (TEM) analysis. All the analysis reveals that zinc oxide nanoparticles were $36 \pm 5 \mathrm{~nm}$ in size. Functional groups and chemical composition of zinc oxide were also confirmed. Tabernaemontana mediated zinc oxide nanoparticles showed effective cytotoxic effect against MCF-7 breast cancer cell lines with an $\mathrm{IC}_{50}$ value of $30.65 \mu \mathrm{g} / \mathrm{ml} / 24 \mathrm{~h}$ by the MTT assay. These results clearly support the benefits of using biological method for synthesizing zinc oxide nanoparticles with anticancer activities.
\end{abstract}

Keywords-Tabernaemontana divaricate, zinc oxide, anticancer, MTT assay

\section{INTRODUCTION}

Plants and/or their extracts provide a biological synthesis route of several metallic nanoparticles which are more ecofriendly and allow controlled synthesis with well-defined size and shape [1]. The enzymes [2], plant leaf extract [3] and bacteria [4] play vital role in green synthesis of zinc oxide nanoparticles. T. divaricata belongs to Apocynaceae family. Crude extract of this plant has anti-infection, anti-parasitic, antibacterial, antifungal and anti-inflammation activity [5, 6]. Aqueous extract of $T$. divaricata leaf has rich phytochemicals such as alkaloids, tannins, Flavonoids, phytosterols, phenols, terpenes and carbohydrates. Flavonoids are known to be synthesised by plants in response to microbial infections [7].

Rajeshwari Sivaraj is with the Biotechnology Department, Karpagam University, Eachanari, Coimbatore 21, Tamil Nadu, India (corresponding author’s e-mail: rajeshwarishivaraj@gmail.com).

Pattanathu KSM Rahman is with the Biotechnology Department, School of science and Technology, University of Teesside, Middlesbrough- TS13BA, UK.

P. Rajiv is with the Biotechnology Department, Karpagam University, Eachanari, Coimbatore 21, Tamil Nadu, India

Rajendran Venckatesh is with the Chemistry Department, Government Arts College, Udumalpet 642 126, Tamil Nadu, India.
Zinc oxide nanoparticles are an important semiconductor material due to unique optical and electrical properties [8,9]. It has application on solar cells, gas sensors, ceramics, catalysts and cosmetics [10]. Nanotechnology has vital role in advances in medicinal research, reproductive science and technology, transfer of agricultural and food wastes to energy and other useful by-products through enzymatic nanobioprocessing, disease prevention, and treatment in plants using various nanocides [11]. The wide application of nanomaterials has caused toxicity to concerned mammals (including mammalian cell cultures) and aquatic species, soil invertebrates, soil microorganisms, or plants [12-14]. Engineered nanoparticles could sequester nutrients on their surfaces and thus serve as a nutrient stock to the organisms, particularly those engineered nanoparticles having high specific surface area. These positive effects could be probably due to the antimicrobial properties of engineered nanoparticles, which can enhance strength and resistance of plants and animals to stress [15]. In this paper, we adopt a green chemistry approach for the synthesis of zinc oxide nanoparticles from plant extract and particle's shape and size were detected by the influence of various standard techniques. Anticancer activity of green synthesized zinc oxide nanoparticles was determined against MCF-7 breast cancer cell lines. Based on our observation and analysis, zinc oxide nanoparticles have effective anticancer activity.

\section{Materials AND MethodS}

A. Synthesis and Characterization of Tabernaemontana mediated zinc oxide nanoparticles

Tabernaemontana divaricate leaves were collected from in and around Karpagam University, Eachanari, Coimbatore, India. All the chemicals and solvents used in this experiment were of analytical grade and were obtained from SigmaAldrich Chemicals, India.

\section{B. Synthesis and Characterization of Tabernaemontana mediated zinc oxide nanoparticles}

Zinc oxide nanoparticles were synthesized via biological reduction of zinc nitrate by $50 \%$ plant extract of Tabernaemontana as described by Sangeetha et al. [16] with small modification. Synthesized nanoparticle's purity and 
grain size were analysed using X-ray diffraction (PerkinElmer spectrum one instrument). Phyto mediated zinc oxide nanoparticles were characterized by Raman spectroscopy (Perkin-Elmer 1725x). The nanoparticles average size and shape were determined by Transmission electron microscopy (TEM) (Model JSM 6390LV, JOEL, USA).

\section{Anticancer activity of Tabernaemontana mediated zinc oxide nanoparticles}

Human breast MCF-7 cell lines (cell culture) were obtained from the National Centre for Cell Science (NCCS), Pune, India. The cells were cultured in Eagles Minimum Essential Medium (EMEM) added with FBS $\left(10 \%\right.$, v/v) at $37{ }^{\circ} \mathrm{C}$ in a $\mathrm{CO}_{2}$ incubator $\left(95 \%\right.$ air, $5 \% \quad \mathrm{CO}_{2}$ and $100 \%$ relative humidity). In order to evaluate the cytotoxic effect of the green synthesised copper oxide nanoparticles against MCF-7 cells, the cells were collected in the exponential stage of growth, seeded into 96-well plates (15,000 per well) and permitted to adhere for $48 \mathrm{~h}$. Then, Different concentrations $(6.5,12.5,25,50,100 \mu \mathrm{g} / \mathrm{ml})$ of Tabernaemontana mediated copper oxide nanoparticles were added to the desired wells and incubated for $48 \mathrm{~h}$. A $20 \mu \mathrm{l}$ of EMEM medium having MTT ( $5 \mathrm{mg} / \mathrm{mL}$ ) was added to each well and incubated for 4 h at $37^{\circ} \mathrm{C}$. Later, the medium was altered with $100 \mu \mathrm{L}$ of DMSO, and optical densities were measured at $570 \mathrm{~nm}$. All studies were performed in triplicates and expressed as the mean \pm standard error.

\section{Statistical analysis}

Experiments were carried out in a randomized block design with three replications and repeated twice. The data were analysed using one way analysis of variance (ANOVA) by software SPS version 16.

\section{Results AND Discussion}

X-ray diffraction was taken for confirmation of zinc oxide phase of the nanoparticles. The XRD pattern of zinc oxide nanoparticles is shown in Fig. 1. The XRD peaks were identified as (100), (002), (101), (102), (110), (112) and (202) reflections, respectively. The narrow and strong diffraction peaks indicate spherical and well crystalline nature of zinc oxide is comparison with the data from JCPDS card No. 897102. The Scherrer formula was used for calculate the particles sizes and was found to be in the range of $30-38 \mathrm{~nm}$ [17].

The Raman spectra of zinc oxide nanoparticles are shown in Fig. 2. The strong peak of $437 \mathrm{~cm}^{-1}$ denotes the zinc oxide nanoparticles phase. The peak $437 \mathrm{~cm}^{-1}$ is due to the Raman active $E_{2}$ optical phonon mode from the zinc oxide nanoparticles. This peak confirmed that zinc oxide nanoparticles have the crystal structure. Other peak at 580 $\mathrm{cm}^{-1}$ characterizes the EIL mode and it attributed to zinc interstitials or oxygen vacancies. High intensity $E_{2}$ mode was present and conforms to pure crystalline zinc oxide nanoparticles.

Fig. 3 shows the transmission electron micrograph of the zinc oxide sample. These Figures undoubtedly indicate the morphology of the particles to be spherical. Some of the particles are agglomerates. TEM image confirms the formation of zinc oxide nanoparticles and it has an average size about $36 \pm 5 \mathrm{~nm}$, which is very similar to previous studies $[16,18]$.

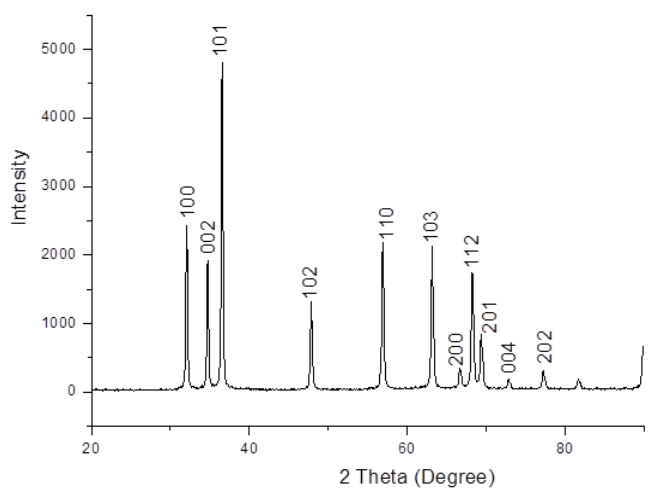

Fig. 1 X-ray diffraction patterns of Tabernaemontana mediated zinc oxide nanoparticles

The cytotoxicity of the zinc oxide nanoparticles was evaluated against MCF-7 breast cancer cell lines at various concentrations (6.5- $100 \mu \mathrm{g} / \mathrm{ml})$. The $\mathrm{IC}_{50}$ value for zincoxide nanoparticles was found to be $30.65 \mu \mathrm{g} / \mathrm{ml}$. Maximum concentration of copper oxide nanoparticles $(100 \mu \mathrm{g} / \mathrm{ml})$ effectively inhibited the growth of cell by more than $97 \%$. Sankar et al. [21] reported the anticancer activity of Origanum vulgare mediated silver nanoparticles and cytotoxic effects of green synthesized $O$. vulgare mediated silver nanoparticles against human lung cancer A549 cells.

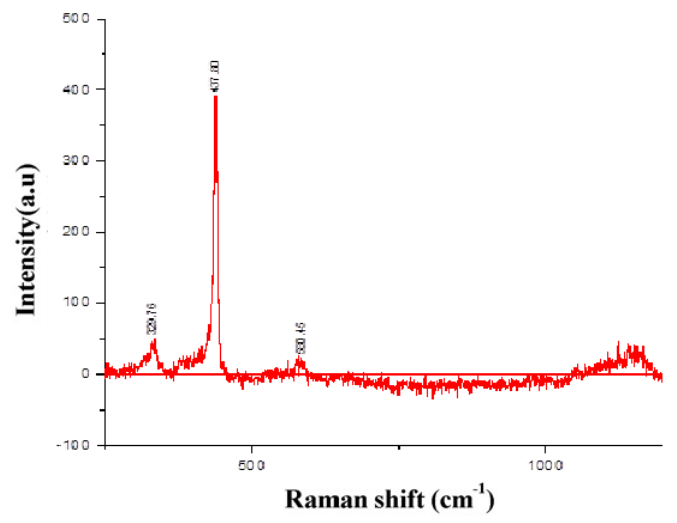

Fig. 2 Raman spectra of Tabernaemontana mediated zinc oxide

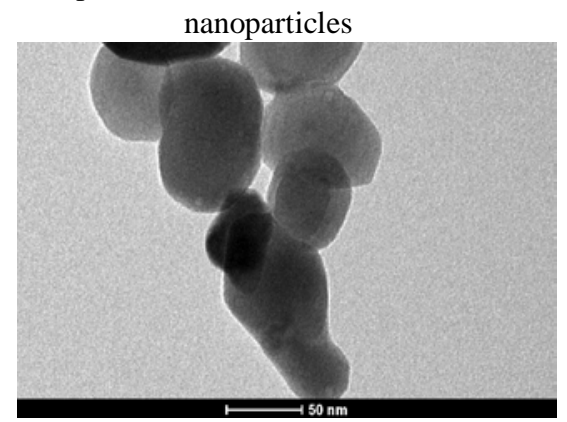

Fig. 3 TEM images of Tabernaemontana mediated zinc oxide nanoparticles 


\section{CONCLUSION}

The present study reported that copper oxide nanoparticles can be synthesized in a simple method using Tabernaemontana leaf extract. The TEM analysis showed that the sizes of the synthesized zinc oxide nanoparticles ranged from $36 \pm 5 \mathrm{~nm}$. Plant mediated zinc oxide nanoparticles showed best anticancer activity.

\section{ACKNOWLEDGMENT}

We thank the Association of commonwealth universities and Commonwealth Commission, United Kingdom for the Commonwealth Academic Fellowship.

\section{REFERENCES}

[1] M H. Bar, D. K. Bhui, G. P. Sahoo, P. Sarkar, S. Pyne, A. Misra, "Green synthesis of silver nanoparticles using seed extract of Jatropha curcas." Colloid Surf. A-Physicochem. Eng. Asp., vol 348, 2009, pp.212-216. http://dx.doi.org/10.1016/j.colsurfa.2009.07.021

[2] K. Prasad, A. K. Jha, "ZnO nanoparticles: synthesis and adsorption study.” Natural Science, vol 1, 2009, pp. 129-135. http://dx.doi.org/10.4236/ns.2009.12016

[3] G. Sangeetha, S. Rajeshwari, R. Venckatesh, "Green synthesis of zinc oxide nanoparticles by aloe barbadensis miller leaf extract: Structure and optical properties.” Mater. Res. Bull., vol 12, 2011, pp. 2560-2566. http://dx.doi.org/10.1016/j.materresbull.2011.07.046

[4] C. Jayaseelan, A. Abdul Rahuman, A. Vishnu Kirthi, S. Marimuthu, T. Bagavan, A. Santhoshkumar, K. Gaurav, L. Karthik, K. V. Bhaskara Rao, "Novel microbial route to synthesize $\mathrm{ZnO}$ nanoparticles using Aeromonas hydrophila and their activity against pathogenic bacteria and fungi.” Spectrochimica Acta Part A., vol 90, 2012, pp. 78-84. http://dx.doi.org/10.1016/j.saa.2012.01.006

[5] T. A. Van Beek, R. Verpoorte, A. B. Svendsen, A. J. Leeuwenberg, N.G. J Ethnopharmacol. Vol 10, 1984, pp. 1-156.

[6] W. Pratchayasakul, A. Pongchaidecha, N. Chattipakorn, S. Chattipakorn, Indian J Med Res. vol 127, 2008, pp. 317-335.

[7] S. M. Gopinath, T. B. Suneetha, V. D. Mruganka, S. Anandha, Int J Res Phychem Pharmacol. vol 1, 2011, pp. 211-213.

[8] M. H. Huang, S. Mao, H. Feick, H. Y. Yan, Wu, H. Kind, E. Weber, R. Russo, P. Yang, "Room-temperature ultraviolet nanowire nanolasers." Science, vol 292, 2001, pp. 1897-1899. http://dx.doi.org/10.1126/science.1060367

[9] L. Vayssieres, K. Keis, A. Hagfeldt, S. E. Lindquist, "Three-dimensional array of highly oriented crystalline $\mathrm{ZnO}$ microtubes.” Chem. Mater., vol 13, 2001, p. 4395. http://dx.doi.org/10.1021/cm011160s

[10] G. Sangeetha, S. Rajeshwari, R. Venckatesh, "Green synthesis of zinc oxide nanoparticles by aloe barbadensis miller leaf extract: Structure and optical properties.” Mater. Res. Bull., vol 12, 2011, pp. 2560-2566. http://dx.doi.org/10.1016/j.materresbull.2011.07.046

[11] R. Wahab, Y. S. Kim, D. S. Lee, J. M. Seo, H. S. Shin, "Controlled synthesis of zinc oxide nanoneedles and their transformation to microflowers.” Sci. Adv. Mater., vol 2, 2010, pp. 424-435. http://dx.doi.org/10.1166/sam.2010.1064

[12] I. U. Carmen, P. Chithra, Q. Huang, P. Takhistov, S. Liu, J. L. Kokini, "Nanotechnology - A New Frontier in Food Science." Food Sci. Technol., vol 57, 2001, pp. 24-29.

[13] US-EPA, "US Environmental Protection Agency Nanotechnology White Paper”. US Environmental Protection Agency. 2007, p 132.

[14] P. Christian, F. Von der Kammer, M. Baalousha, T. Hofmann, "Nanoparticles: Structure, properties, preparation and behaviour in environmental media.” Ecotoxicology, vol 17, 2008, pp. 326- 343. http://dx.doi.org/10.1007/s10646-008-0213-1

[15] S. J. Klaine, P. J. J. Alvarez, G. E. Batley, T. F. Fernandes, R. D. Handy, D. Y. Lyon, S. Mahendra, M. J. McLaughlin, J. R. Lead, "Nanomaterials in the environment: Behavior, fate, bioavailability and effects." Environ. Toxicol. Chem., vol 27, 2008, pp. 1825-1851. http://dx.doi.org/10.1897/08-090.1
[16] H. Bar, D. K. Bhui, G. P. Sahoo, P. Sarkar, S. Pyne, A. Misra, "Green synthesis of silver nanoparticles using seed extract of Jatropha curcas." Colloid Surf. A-Physicochem. Eng. Asp., vol 348, 2009, pp.212-216. http://dx.doi.org/10.1016/j.colsurfa.2009.07.021

[17] H. Borchert, E. V. Shevchenko, A. Robert, I. Mekis, A. Kornowski, G. Grabel, H. Weller, "Determination of Nanocrystal Sizes: A Comparison of TEM, SAXS, and XRD Studies of Highly Monodisperse CoPt3 Particles.” Langmuir, vol 21, 2005, pp. 1931-1936. http://dx.doi.org/10.1021/la0477183

[18] N. Jones, B. Ray, R. T. Koodali, A. C. Manna, "Antibacterial activity of $\mathrm{ZnO}$ nanoparticle suspensions on broad spectrum of microorganisms." FEMS Microbiol. Lett., 279, 2008, pp. 71-76. http://dx.doi.org/10.1111/j.1574-6968.2007.01012.x

[19] R. Sankar, A. Karthik, A. Prabu, S. Karthik, K. S. Shivashangari, V. Ravikumar, Colloids Surf. B. vol 108, 2013, pp. 80- 84. http://dx.doi.org/10.1016/j.colsurfb.2013.02.033 